\title{
Studies on Antiviral Activity of Zeolite Against Foot and Mouth Disease and Ephemeral Fever Viruses
}

\author{
Assem, A. Mohamed ${ }^{1 *}$, Moustafa Amin ${ }^{2}$ \\ ${ }^{I}$ Department of FMD, Veterinary Serum and Vaccine Research Institute (VSVRI), Abassia, Cairo, Egypt \\ ${ }^{2}$ Central Laboratory for Evaluation of Veterinary Biologics, Abbasia, Cairo
}

*Corresponding Author: Assem A Mohamed, Department of FMD, Veterinary Serum and Vaccine Research Institute (VSVRI), Abassia, Cairo, Egypt.Email: svri@idsc.gov.eg

\begin{abstract}
The aim of this study was to evaluate the antiviral properties of clinoptilolite zeolite, a natural nontoxic zeolite. Herein, a fine powder of micronized zeolite (MZ) was obtained by mechanical micronization of natural clinoptilolite. Different viral suspensions were treated with $\mathrm{MZ}$ in concentrations ranging from 10 to $50 \mathrm{mg} / \mathrm{ml}$. The viral proliferation was evaluated by optical microscope as percentage of cytopathic effect $(C P E)$. Foot and mouth disease virus (FMD) types $O$ panAsia, A and SAT2 and Bovine ephemeral fever $(B E F)$ virus were used in the antiviral assay. With concentrations of 10 and $20 \mathrm{mg} / \mathrm{ml}$ of MZ little or no antiviral effect was observed at all, while concentrations of 30 to $50 \mathrm{mg} / \mathrm{ml}$ of $\mathrm{MZ}$ induced a significant inhibitory effect upon viral proliferation. The antiviral effect of MZ seems to be non-specific and is more likely based on the incorporation of viral particles into pores of MZ aggregates than ion exchange properties of clinoptilolite. Our results indicate a possibility of therapeutic application of MZ, either locally (skin) and could also be used in purification of drinking water from different viruses.
\end{abstract}

\section{INTRODUCTION}

Clinoptilolite is a natural, non-toxic zeolite that has monoclinic crystal structure symmetry and strong adsorptive and ion exchange capacity [1]. These properties have been largely exploited in industrial, agricultural, environmental and biological technologies [2]. Zeolites also possess biological activities, either positive or negative. The best known and documented positive biological activity of natural clinoptilolite is its action as antidiarrheal drug [3]. Furthermore, some of them seem to have antibacterial property [4].

Clinoptilolite administered by gastric intubation to mice injected with melanoma cells significantly reduced the number of melanoma metastases [2]. Clinoptilolite treatment of mice and dogs suffering from a variety of tumor types led to improvement in the overall health status, prolongation of life span, and decrease in tumor size. Local application of clinoptilolite to skin cancers of some dogs effectively reduced tumor formation and growth [6].

The major negative biological effect of clinoptilolite could be its toxicity in higher organisms (mammal) if the content of heavy metals $(\mathrm{Pb}, \mathrm{Cd}, \mathrm{Zn}$, etc. $)$ is high.
Therefore, a classic acute, sub-chronic and chronic toxicity study of the clinoptilolite from was performed on mice and rats [6,9]. Results clearly show that oral (in diet) administration of clinoptilolite to mice and rats for 6 and 12 months, respectively, caused no changes that could be considered a toxic effect of treatment.

Our results assumed that the adsorbent qualities and ion exchange properties of clinoptilolite could be effective on viruses too. Herein, we tested a natural clinoptilolite on in vitro viral replication of Foot and mouth disease virus types O panAsia, A and SAT2 and ephemeral fever virus.

\section{MAterials AND MeTHOD}

\subsection{Natural Clinoptilolite}

A fine powder of natural clinoptilolite, i.e., micronized zeolite (MZ), was obtained by mechanical micronization [6] of natural clinoptilolite from Zeolith Bentonit Versand, Germany. Chemical composition and characteristics of MZ have been described previously $[5,6]$.

\subsection{Cell Lines}

Baby hamster kidney cells (BHK) were used. Cells were propagated in modified eagle 
medium (MP, France) supplemented with $10 \%$ newborn calf serum (AusGeneX, Australia), 1\% L-glutamine and $0.3 \%$ sodium bicarbonate at 37 C.

\subsection{Viruses}

Vaccine strains of Foot and mouth disease virus types O panAsia, A and SAT2 and ephemeral fever virus from Veterinary Serum and Vaccine Research Institute (VSVRI), Abassia, Cairo, Egypt, were included in this study. Viruses were propagated on BHK cells. The viral suspension consisted the cell-free supernatant collected after centrifugation $(20 \mathrm{~min}, 4 \mathrm{C}, 3000 \times \mathrm{g})$ of infected media (MEM supplemented with $2 \%$ FBS) collected at maximal viral proliferation, i.e. $100 \%$ cytopathic effect (CPE) of whole cell monolayer. Five different relative viral titers $\left(\mathrm{V}^{1}-\mathrm{V}^{-4}\right)$ obtained by serial dilution of viral suspension [1:10 for FMD viruses and 1: 2 for $\mathrm{BEF}$ virus] were treated with $\mathrm{MZ}$ prior to antiviral assay.

\subsection{MZ Treatment}

Due to sedimentation of clinoptilolite in its water suspension, it is not possible to treat a cell culture with MZ and further follow up morphological changes of cells upon viral infection. For this reason, different viral titers $\left(\mathrm{V}^{1}-\mathrm{V}^{-4}\right)$ and MEM supplemented with $2 \%$ FBS (negative control) were treated with $\mathrm{MZ}$ at concentrations ranging from 10 to $50 \mathrm{mg} / \mathrm{ml}$. After incubation ( $15 \mathrm{~h}, 4 \mathrm{C}$, constant rotation), the suspension (media and MZ) was centrifuged $(10 \mathrm{~min}, 4 \mathrm{C}, 3000 \times \mathrm{g})$ to separate the liquid from the solid phase (MZ).

\subsection{Antiviral Assays}

BHK cells were seeded at $2 \times 10^{4}$ cells per $\mathrm{ml}$ on 24 well flat-bottomed microtitre plates (Becton Dickinson, USA). The viral infection was performed on confluent cell monolayers. The plates were incubated at $37 \mathrm{C}$ and the CPE were followed by optical microscopy after $24 \mathrm{~h}-48 \mathrm{~h}$ for FMD virus and from 1 day to 8 days for BEF. Each assay was done four times. The inhibitory effect of viral proliferation was evaluated as percentage of CPE and was compared to CPE of similar dilutions of viral suspension also incubated at $4 \mathrm{C}$ during $15 \mathrm{~h}$ but without MZ (positive control).

\section{RESULTS AND DISCUSSION}

Two types of viruses were chosen on the basis of their morphology. The ephemeral fever virus capsid is surrounded by a lipoprotein envelope while Foot and mouth disease viruses are not enveloped. Both test viruses are single stranded RND viruses while ephemeral fever virus has negative sense genome. Both test viruses are highly infective and specific CPE appears in cell culture (BHK), within 1 day to 8 days depending of the viral titre (serial dilution 1:10 for FMD and 1: 2 for BEF).

The influence of clinoptilolite on viral proliferation depends on both the concentration of MZ (ranging 10 to $50 \mathrm{mg} / \mathrm{ml}$ ) and the viral titre (ranging from $\mathrm{V}^{1}$ to $\mathrm{V}^{-4}$ ), i.e. antiviral effect. The antiviral effect was highest with the highest concentration of clinoptilolite $(50 \mathrm{mg} / \mathrm{ml})$ and the lowest viral titre $\left(\mathrm{V}^{-4}\right)$. The observed percentages of antiviral effect also depended on the type of virus (Tables 1-4).

For FMD virus O-panAsia, Concentrations of $10,20,30,40,50 \mathrm{mg} / \mathrm{ml}$ of $\mathrm{MZ}$ induced a maximum of $5.7 \%\left(\mathrm{~V}^{-4}\right), 14.2 \%\left(\mathrm{~V}^{-4}\right), 33.1 \%$ $\left(\mathrm{V}^{-4}\right), 78.8 \%\left(\mathrm{~V}^{-4}\right), 94.6 \%\left(\mathrm{~V}^{-4}\right)$ inhibition of CPE, respectively (Table 1).

Table1. Percentage of inhibition of FMD virus $O$ panAsia proliferation upon treatment with $M Z$

\begin{tabular}{|l|l|l|l|l|l|}
\hline \multirow{2}{*}{$\begin{array}{l}\text { MZ } \\
(\mathrm{mg} / \mathrm{ml})\end{array}$} & \multicolumn{5}{|c|}{ Viral titre } \\
\cline { 2 - 6 } & $\mathrm{V}^{-4}$ & $\mathrm{~V}^{-3}$ & $\mathrm{~V}^{-2}$ & $\mathrm{~V}^{-2}$ & $\mathrm{~V}^{1}$ \\
\hline 10 & 5.7 & 3.3 & 0 & 0 & 0 \\
\hline 20 & 14.2 & 12 & 10.3 & 6 & 2.8 \\
\hline 30 & 33.1 & 27 & 21 & 15 & 12.5 \\
\hline 40 & 78.8 & 52 & 45 & 41.2 & 38 \\
\hline 50 & 94.6 & 81 & 79 & 68.2 & 61 \\
\hline
\end{tabular}

For FMD virus A, Concentrations of 10, 20, 30, $40,50 \mathrm{mg} / \mathrm{ml}$ of MZ induced a maximum of $6 \%$ $\left(\mathrm{V}^{-4}\right), 17 \%\left(\mathrm{~V}^{-4}\right), 36.2 \%\left(\mathrm{~V}^{-4}\right), 73 \%\left(\mathrm{~V}^{-4}\right), 96.3$ $\%\left(\mathrm{~V}^{-4}\right)$ inhibition of CPE, respectively (Table 2).

Table2. Percentage of inhibition of FMD virus $A$ proliferation upon treatment with $M Z$

\begin{tabular}{|l|l|l|l|l|l|}
\hline \multirow{2}{*}{$\begin{array}{l}\text { MZ } \\
(\mathrm{mg} / \mathrm{ml})\end{array}$} & \multicolumn{5}{|c|}{ Viral titre } \\
\cline { 2 - 6 } & $\mathrm{V}^{-4}$ & \multicolumn{1}{|c|}{$\mathrm{V}^{-3}$} & \multicolumn{1}{|c|}{$\mathrm{V}^{-2}$} & \multicolumn{1}{c|}{$\mathrm{V}^{-2}$} & $\mathrm{~V}^{1}$ \\
\hline 10 & 6 & 4.8 & 0 & 0 & 0 \\
\hline 20 & 17 & 13.4 & 10 & 8.5 & 5 \\
\hline 30 & 36.2 & 25 & 20.8 & 15.7 & 12 \\
\hline 40 & 73 & 62 & 55.4 & 41 & 37 \\
\hline 50 & 96.3 & 86 & 77.2 & 69 & 65 \\
\hline
\end{tabular}

For FMD virus SAT 2, Concentrations of 10, $20,30,40,50 \mathrm{mg} / \mathrm{ml}$ of $\mathrm{MZ}$ induced a maximum of $5.8 \%\left(\mathrm{~V}^{-4}\right), 18 \%\left(\mathrm{~V}^{-4}\right), 38 \%\left(\mathrm{~V}^{-}\right.$ $\left.{ }^{4}\right), 77 \%\left(\mathrm{~V}^{-4}\right), 92 \%\left(\mathrm{~V}^{-4}\right)$ inhibition of $\mathrm{CPE}$, respectively (Table 3 ). 
Table3. Percentage of inhibition of FMD virus SAT2 proliferation upon treatment with $M Z$

\begin{tabular}{|l|l|l|l|l|l|}
\hline \multirow{2}{*}{$\begin{array}{l}\text { MZ } \\
(\mathrm{mg} / \mathrm{ml})\end{array}$} & \multicolumn{5}{|c|}{ Viral titre } \\
\cline { 2 - 6 } & $\mathrm{V}^{-4}$ & \multicolumn{1}{|c|}{$\mathrm{V}^{-3}$} & \multicolumn{1}{|c|}{$\mathrm{V}^{-2}$} & \multicolumn{1}{c|}{$\mathrm{V}^{-2}$} & $\mathrm{~V}^{1}$ \\
\hline 10 & 5.8 & 3.1 & 0 & 0 & 0 \\
\hline 20 & 18 & 15.4 & 10.8 & 6.5 & 3 \\
\hline 30 & 38 & 25.4 & 21 & 15 & 12.8 \\
\hline 40 & 77 & 56 & 45.3 & 41 & 38.3 \\
\hline 50 & 92 & 84 & 76.1 & 65.3 & 58 \\
\hline
\end{tabular}

For BEF virus, Concentrations of 10, 20, 30, 40, $50 \mathrm{mg} / \mathrm{ml}$ of $\mathrm{MZ}$ induced a maximum of $17 \%$ $\left(\mathrm{V}^{-4}\right), 15.7 \%\left(\mathrm{~V}^{-4}\right), 42.4 \%\left(\mathrm{~V}^{-4}\right), 64.6 \%\left(\mathrm{~V}^{-4}\right)$, $98 \%\left(\mathrm{~V}^{-4}\right)$ inhibition of $\mathrm{CPE}$, respectively (Table 4).

Table4. Percentage of inhibition of BEF proliferation upon treatment with $M Z$

\begin{tabular}{|l|l|l|l|l|l|}
\hline \multirow{2}{*}{$\begin{array}{l}\text { MZ } \\
(\mathrm{mg} / \mathrm{ml})\end{array}$} & \multicolumn{5}{|c|}{ Viral titre } \\
\cline { 2 - 6 } & $\mathrm{V}^{-4}$ & $\mathrm{~V}^{-3}$ & $\mathrm{~V}^{-2}$ & $\mathrm{~V}^{-2}$ & $\mathrm{~V}^{1}$ \\
\hline 10 & 17 & 15 & 11 & 9.5 & 9 \\
\hline 20 & 15.7 & 14 & 12.9 & 9 & 8 \\
\hline 30 & 42.4 & 38 & 34.4 & 29.3 & 22 \\
\hline 40 & 64.6 & 56 & 49.5 & 39.3 & 32.9 \\
\hline 50 & 98 & 90 & 84 & 77 & 70.8 \\
\hline
\end{tabular}

Our study indicates an inhibitory effect of MZ upon viral proliferation. The inhibitory effect was represented by the inhibition of specific viral CPE on cell culture compared to the same without treatment with MZ. As mentioned previously, the inhibitory effect of $\mathrm{MZ}$ depends on the concentration of MZ (10-50 mg/ml), the type and the concentration of virus (viral titre ranging from $\mathrm{V}^{1}$ to $\mathrm{V}^{-4}$ ) (Tables 1-4). A significant inhibition of viral proliferation over $50 \%$ was observed with concentration of $\mathrm{MZ}$ of $50 \mathrm{mg} / \mathrm{ml}$.

The inhibition of viral proliferation must probably be unspecific and independent of virion size, structure and genome type. As MZ consists of a mixture of particles of approximately $1 \mathrm{um}$ in diameter and an internal pore size of $0.35 \mathrm{~nm}$, virions ranging from 20 to $200 \mathrm{~nm}$ in size were probably incorporated within the mesoporous zeolite aggregate and/or adsorbed on the surface of their crystalline microstructure during the $15 \mathrm{~h}$ treatment of virally infected culture media. This would be the most plausible explanation because a similar phenomenon is used in the method of viral concentration by capture on borosilicate glass powder although the particle size is much larger (100-200 um) [10]. Furthermore, MZ adsorb essential minerals and amino acids from culture media [11]. Inhibition of viral proliferation by capture and/or adsorption of virions onto MZ crystalline microstructure requests further research (electron microscopy analysis, for instance). Another possible mechanism of action of $\mathrm{MZ}$ onto viral particles is its ion exchange capability that could destabilize morphology of viral particles, namely as lipoprotein structure (viral envelope) is less resistant to environment than protein (viral capsid), this could explain why BEF (enveloped) were more destabilized than FMD viruses (non-enveloped) by MZ.

The exact mechanism of action of MZ based on the ion exchange property of their interaction with viral particles in an aqueous solution (culture media), needs further investigation, extensive biochemical analysis of media and virion changes. The mechanisms of action of MZ upon different types of viruses are probably non-specific which makes it more interesting than conventional antiviral drug [12]. Such inactivation of viral particles by $\mathrm{MZ}$ would be extremely interesting for viruses that infect the digestive tract such as enteroviruses and adenoviruses, and because MZ can be orally administrated without toxicity [6] it could be used for therapeutic purposes. Beside that, MZ could be used as traditional natural antidiarrheal therapy such as clay and activated charcoal $[12,13]$. This is why new efficient and inexpensive potential drugs such as MZ could be helpful to inhibit, if not eradicate, viral infections. Additionally, MZ could be administrated locally on skin as cream or gel in order to inhibit FMD virus skin lesions that are often very painful.

\section{CONClusion}

Our preliminary results, indicate an antiviral property of clinoptilolite that open a possibility of therapeutic application of MZ either locally (skin). However, the inhibitory effect of viral proliferation was observed with high concentration of MZ (30 mg/ml or more) which makes the clinical applications and the doseresponse effect difficult to establish. Fortunately, MZ could be used in purification of drinking water from different viral particles without concern of concentration of $\mathrm{MZ}$ for application.

\section{REFERENCES}

[1] D.W.J. Breck, Chem. Educ. 41 (1964) 678.

[2] F.A. Mumpton, Proc. Natl. Acad. Sci. USA 96 (1999) 3463.

[3] G. Rodriguez-Fuentes, M.A. Barrios, A. Iraizoz, I. Perdomo, B. Cedre, Zeolites 19 (1997) 441. 
[4] T. Maeda, Y. Nose, Artif. Organs 23 (1999) 129.

[5] K. Pavelic', M. Katic', V. S`verko, T. Marotti, B. Bošnjak, T. Balog, R. Stojkovic', M. Radac `ic', M. C` olic’, M. Poljak-Blaz`i, J. Cancer Res. Clin. Oncol. 128 (2002) 37.

[6] K. Pavelic', M. Hadz ija, L. Bedrica, J. Pavelic', I. Đikic', M. Katic', M; Kralj, M. Herak Bosnar, S. Kapitanovic', M. PoljakBlaz i, S. Križanac, R. Stojkovic', M. Jurin, B. Subotic', M. C` olic', J. Mol. Med. 78 (2001) 708.

[7] M. Poljak-Blaz`i, M. Katic', M. Kralj, N. Z arkovic', T. Marotti, B. Bošnjak, V. C` verko, T. Balog, K. Pavelic', Stud. Surf. Sci. Catal. 135 (2001) 170.
[8] K. Pavelic', B. Subotic', M. C olic', Surf. Sci. Catal. 135 (2001) 374.

[9] I. Martin-Klein, Z. Flegar Mastric', R. Zadro, D. Breljak, S. Stanovic' Janda, R. Stojkovic', M. Marus 'ic', M. Radac 'ic', M. Boranic', Food Chem. Toxicol. 39 (2001) 717.

[10] D. C ` ečuk, M. Grce, Rev. Epide'm. Sante' Publ. 40 (1992) 182.

[11] M. Katic', Molecular mechanisms of clinoptilolite on tumor cells. Ph.D. thesis, University of Zagreb, 2002.

[12] J.M. Hunter, Science 228 (1985) 1040.

[13] M.J. Rodman, R.N. 43 (1980) 58.

[14] E.J. De Clercq, Clin. Virol. 22 (2001) 73

Citation: Assem A Mohamed. Studies on Antiviral Activity of Zeolite Against Foot and Mouth Disease and Ephemeral Fever Viruses. ARC Journal of Animal and Veterinary Sciences. 2019; 5(1):31-34. doi: dx.doi.org/10.20431/2455-2518.0501005.

Copyright: (c) 2019 Authors. This is an open-access article distributed under the terms of the Creative Commons Attribution License, which permits unrestricted use, distribution, and reproduction in any medium, provided the original author and source are credited. 